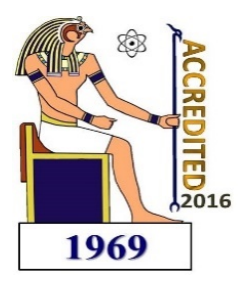

Delta Journal of Science

Available online at

https://djs.journals.ekb.eg/

Research Article

\title{
Three-Dimensional Hydrocarbon Potentiality Modeling of the Source/Reservoir Rocks of the Alam El Bueib and Khatatba Formations, Shoushan Basin, North Western Desert, Egypt
}

\author{
Alaa A. Masoud ${ }^{1 *}$, Abdel Moneim N. Abu Shady ${ }^{2}$, Abdelaziz Abdeldayem ${ }^{1}$, and Mai El Sherief ${ }^{1}$ \\ *Corresponding author e-mail address: alaa_masoud@science.tanta.edu.eg \\ ${ }^{1}$ Geology Department, Faculty of Science, Tanta University, 31527 Tanta, Egypt \\ ${ }^{2}$ Khalda Petroleum Company, New Maadi, P.O Box 560, Maadi, Cairo, Egypt
}

\begin{abstract}
The present research aims at modeling in three-dimensional (3D) the highly productive hydrocarbon zones of the Cretaceous Alam El Bueib (AEB) and Jurassic Khatatba formations located in the TUT oil field, Shoushan Basin, North Western Desert. This is based on the assessment of the geochemical and petrophysical characteristics of the two formations to help effective setting of future exploration plans. Geochemical and petrophysical analyses were carried out using PetroMod 11 and Interactive Petrophysics (IP) 3.6, respectively. 3D Modeling has been carried out integrating Voxler 3 software in a GIS environment to enable building a permanent geodatabase of the subsurface geological conditions, and trace lateral and vertical lithofacial variations and changes in thickness of different source and reservoir rocks. Source rock evaluation using Total Organic Content (TOC), free hydrocarbon (S1), residual hydrocarbon potential (S2), hydrogen Index (HI), Genetic Potential (GP) and maximum Temperature (Tmax) geochemical parameters and vitrinite reflectance (Ro \%) from one well was used to predict hydrocarbon maturation and time of its generation. Petrophysical data analysis comprising total thickness, shale volume, total porosity, effective porosity, water saturation, hydrocarbon saturation, residual and movable hydrocarbons helped in determining production zones, reservoir and pay thicknesses, and distinguishing of gas, oil, and water contacts. The results of organic geochemical analysis clarify an early stage of hydrocarbon generation during Late Cretaceous at about 68 my and 92 my for the AEB and Khatatba formations, respectively. The temperature of maximum pyrolytic hydrocarbon generation ranges from $430{ }^{\circ} \mathrm{C}$ to $460{ }^{\circ} \mathrm{C}$, reflecting thermally mature organic matter. The average value of TOC (wt \%) are 0.88 and 6.69 for the AEB and Khatatba formations, respectively. Majority of samples from the AEB Formation show poor to good organic matter quality of kerogen type III (gas prone) while those from the Khatatba Formation yielded poor to very good quality of kerogen type II (oil with some gas) and type III (gas-prone). Petrophysically, the percentages of effective porosity, volume of shale, and hydrocarbon saturation averaged 12.29, 11.57, and 51.8 for AEB Formation, and 9.63, 7.17, and 80.15 for the Khatatba Formation, respectively. The constructed 3D lithofacial, geochemical, and petrophysical models when integrated with the petroleum characterization model enabled the effective evaluation of the petroleum system, hydrocarbon potentiality and possible highly productive hydrocarbon zones.
\end{abstract}

Key words: Hydrocarbon Potential, 3D Modeling, GIS, Shoushan Basin, Egypt.

\section{Introduction:}

Exploration of hydrocarbon occurrences and quality variations within a prospect - prior to drilling - is of large importance in petroleum industry. 3D hydrocarbon potential modeling of the source/reservoir rocks has recently received renewed attention and is now used for future exploration purposes. Such 3D modeling provides a competitive advantage for predicting trapped hydrocarbon accumulations and reduce risk in exploration by avoiding costly drilling mistakes in the future.

Evaluation of hydrocarbon potentiality in the petroleum systems in the north Western Desert province 
(Egypt) has been traditionally performed in 2D maps (Abdelkader, 2012; El-Bastawesy, 2013; Nassar, 2013). Parameter 2D maps commonly abstracts a certain thickness of the lithologic unit into averages of variables, hindering then a full render and better understanding of the variables in the $3 \mathrm{D}$ space. Integrated $3 \mathrm{D}$ modeling provides a strategy for optimizing exploration in frontier areas and evaluating new plays within well-explored basins. The wide areal distribution, huge thickness, and facies characteristics of the subsurface Cretaceous AEB and the Middle Jurassic Khatatba sediments have recently attracted the attention of many petroleum geologists (e.g., Carlos et al. 2001; Zein El-Din et al. 2001; Abdou et al. 2009; Shalaby et al. 2013).

The hydrocarbon potentiality of the Middle Jurassic and the Lower Cretaceous source rocks in the North Western Desert basin has been discussed by many authors. El Nady and Ghanem (2011) proposed a shallow marine environment for the Khatatba Formation and a fluviodeltaic environment for the AEB Formation. Early stage of hydrocarbon generation was reached Late CretaceousOligocene and Late Cretaceous-Eocene for AEB Formation and Khatatba Formation, respectively. The Khatatba Formation is considered as an important source rock, while AEB Formation as an effective source rock for hydrocarbon accumulation in the south Matruh basin (Sharaf et al., 1999) and as a good source for hydrocarbon generation in the West Razzak-Alamein area (El Nady, 1999). The organic-rich sediments of the Khatatba Formation are considered to have sourced the oil and gas within the Khatatba sandstone reservoirs (Shalaby et al., 2012). Sharaf and El Nady (2003) recognized that the oil from AEB are sourced from Khatatba and AEB source rocks with minor contribution from Kohla source rocks. Ramadan et al. (2012) recognized that the AEB source rock in Tut oil field varies from poor to very good in organic richness of kerogen type III and is characterized by immature to mature phases. The Lower Cretaceous AEB source rocks are moderately mature and has organic matter that were deposited in deltaic environment with significant input of terrestrial, marine algae and bacterial contributions (El Nady, 2015). Basin modeling discriminating the maturity levels and burial history has been successfully applied in Egypt to the Shoushan Basin (Shalaby et al., 2011) and the Matruh- Shoushan Basin (Metwalli and Pigott, 2005).

The present work identifies and evaluates the petrophysical characteristics and hydrocarbon potentiality (hydrocarbon generation quantity/quality) of the subsurface Middle Jurassic and Lower Cretaceous source/ reservoir rocks in ten wells from the TUT Oil Field, Shoushan Basin. It also incorporates basin modeling to evaluate the thermal maturity levels and the burial history of the organic sediments and track the spatial distribution of reservoir rocks.

\section{Material and methods:}

The studied wells are located in the TUT oil field in the northern part of the Western Desert province (Fig. 1) where a number of structurally controlled sedimentary basins with various facies were formed (Issawi et al. 1999). Sandstone with argillaceous and calcareous cement and limestone intervals interbedded with shales deposited in shallow marine environment with more continental influence toward the south (Hanter, 1990) where the Barremian-Early Aptian lithology of AEB sediments dominate (Fig. 2). Sandstones interbedded with coals, and organic-rich shales dominate the Middle Jurassic Khatatba Formation.

Well logs of ten wells (TUT-01X, TUT-03, TUT-11, TUT-21X, TUT-22X, TUT-52, TUT-76, TUT-81, TUT84 and TUT-85) from TUT oil field were used to evaluate the Alam El Bueib (AEB-1, AEB-2, AEB-3A, AEB-3D, AEB-3E) and Khatatba Mesozoic formations. Four wells reached the bottom of AEB Formation and six wells ended at the bottom of the Khatatba Formation. Source rock potential and thermal maturity analyses were carried out using the geochemical data of TUT-22X well. PetroMod 11 and Interactive Petrophysics V3.6 (IP) softwares were used for the geochemical analyses (Rock-Eval pyrolysis and Ro \%) and petrophysical well log data [gamma ray, density, neutron, photoelectric factor (PEF), deep resistivity (LLD), shallow resistivity (LLS), and microspherical resistivity (MSFL)]. Parameters of the total porosity $(\Phi \mathrm{t})$, effective porosity (Фeff), water saturation (Sw), and hydrocarbon saturation resulted from the petrophysical analysis helped in defining the potential reservoirs and pay zones in the two formations.

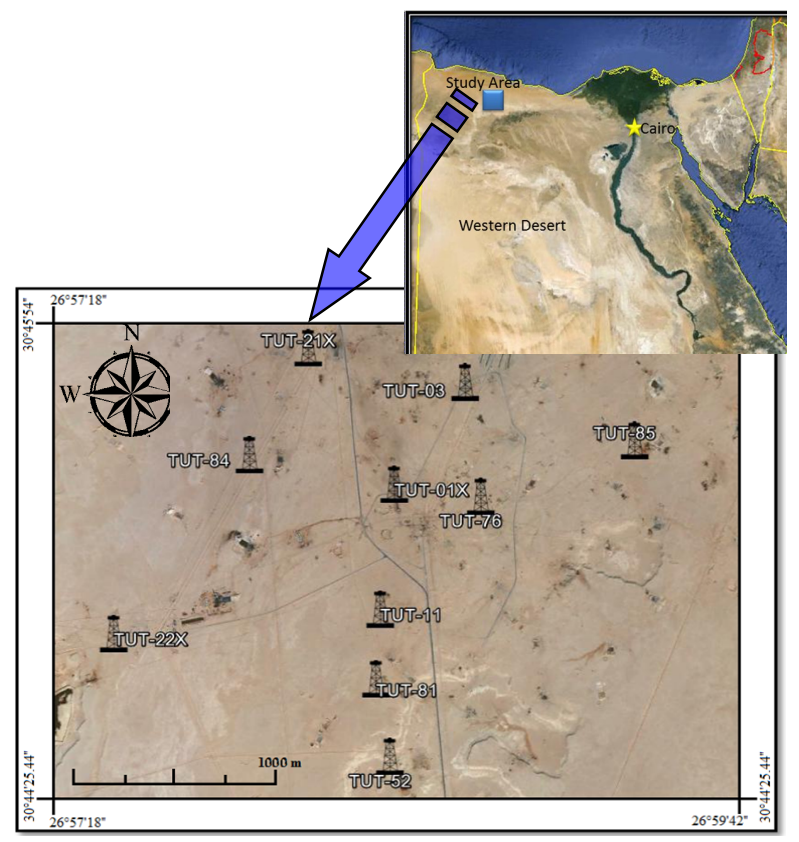

Fig. 1: Location map of the study area and the location of drilled wells in TUT oil field, north Western Desert, Egypt (Google Earth, 2015). 


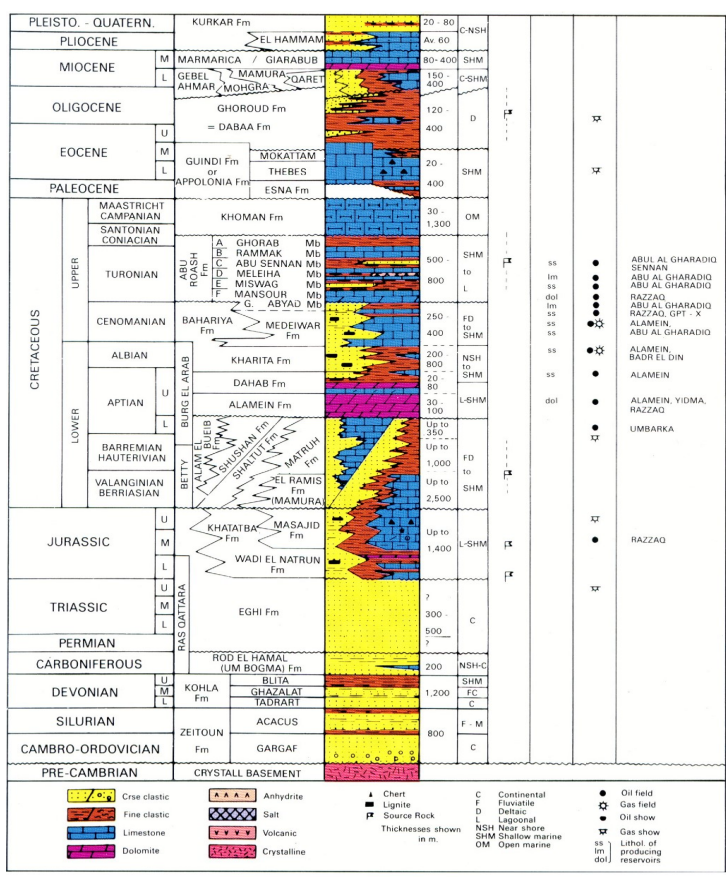

Fig. 2: Litho-stratigraphic section in the northern Western Desert (Schlumberger, 1984 and 1995).

Rock-Eval pyrolysis technique was applied for source rock potential evaluation by measuring the amount of hydrocarbons generated through thermal cracking of the contained kerogen. This method was applied on 74 selected core shale rock samples collected at various depths from AEB (19 samples) and Khatatba (55 samples) lithostratigraphic succession in well TUT-22X (after Khalda, 1996). The samples were finely ground. Total organic carbon (TOC) was determined by carbon analyzer (TOC 2000) after the removal of carbonates by treatment with hydrochloric acid (10\%). Rock-Eval pyrolysis was performed according to the procedure described by Espitalie et al. (1977 and 1985) to obtain S1, S2, S3 and Tmax values. Vitrinite reflectance (Ro \%) measurements were made on thin sections under reflected light. The analysis was performed on a Hewlett Packard 5890 series II instrument equipped with a split-splitless injector, a flame ionization detector and a fused silica capillary (El Nady, 2015). The studied geochemical parameters are Total Organic Carbon (TOC), Volatile hydrocarbon (S1), Remaining hydrocarbon generative potential (S2), Hydrogen Index (HI), Genetic Potential (GP), vitrinite reflectance (Ro \%), and Maximum Temperature (Tmax) of the two formations. Formation tops or true stratigraphic thickness, geologic age of the time-rock unit, geothermal gradient and magnitude of erosion and the non-deposition periods or hiatus were used for the thermal burial history modeling.

To assess the maturation history of potential source rocks, PetroMod 11 software was used for basin modeling to calculate the levels of thermal maturity based on the calibration of measured Ro \% and Tmax against the Lawrence Livermore National Laboratory (LLNL) Easy $\%$ Ro model (Sweeney and Burnham, 1990). The burial history model was constructed using the LLNL Easy Ro $\%$ model, heat flow, stratigraphic thickness derived from the well composite logs, percentages of three lithological facies (sandstone, shale, and limestone), absolute ages, formation temperatures and erosional thickness base on seismic and well log data. Basin modeling simulations were performed using the forward modeling approach and input data from analogous wells in the study area.

Voxler-3, a 3-dimesional (3D) modeling software, was used to build the 3D models of the oil field parameters and render them in space to better understand the key relationships among the parameters governing the spatial variability of the producing formations. GIS geodatabase was built using well coordinates, properties against depth variations including geochemical, mechanical/petrophysical, lithofacies and well logs. The 3D geologic model was integrated with a comprehensive petroleum characterization models to evaluate the petroleum system of source rocks and revisit the hydrocarbon potential of reservoir rocks for the TUT oil field.

\section{Results and Discussion:}

\section{A. Three-dimensional lithologic wells:}

The lithologic models show the spatial distribution of the wells, geographic locations, and variations of lithologic units against depths (Fig. 3). The Khatatba and AEB-3E are the thickest units while AEB-2 and AEB-3D represent the thinnest units in selected formations.

\section{B. Geochemical modeling of source rocks: \\ 1. Source rock evaluation:}

The source rock quality was evaluated based on the TOC (wt \%), volatile hydrocarbon (S1), remaining hydrocarbon generative potential (S2), hydrogen index (HI), genetic potential (GP), and maximum temperature (Tmax) (Fig. 4). Descriptive statistics of the studied parameters are shown in Table 1.

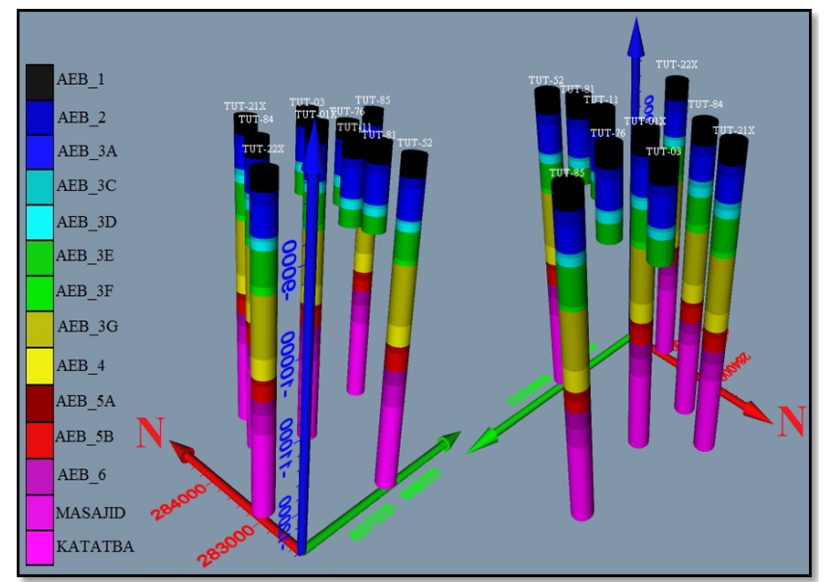

Fig. 3: GIS 3D model of distribution wells in the study area of Alam El Bueib and Khatatba Formations.

According to the classification of Peters (1986), the TOC (wt \%) values that reflect the organic richness, the Khatatba Formation represents a poor to very good source rock with an average TOC value of $6.7 \mathrm{wt} . \%$ and a range of 0.3-33.5 wt. \% compared to the AEB Formation that has a fair to good organic richness with a TOC average of 0.88 wt. $\%$ and a range of $0.53-1.54$ wt. \% (Fig. 4). 
Volatile hydrocarbon (S1) represents the hydrocarbon vaporized and driven off from the sample at low temperature to about $300^{\circ} \mathrm{C}$ and is measured in $\mathrm{mg}$ $\mathrm{HC} / \mathrm{g}$ rock. Khatatba Formation has better source rock quality in terms of $\mathrm{S} 1$ values compared to AEB Formation. S1 indicates poor to very good source rock quality for Khatatba Formation with an average of 0.69 $\mathrm{mg} / \mathrm{g}$ and a range of $0.14-2.21 \mathrm{mg} / \mathrm{g}$; and an average of $0.26 \mathrm{mg} / \mathrm{g}$ and a range of $0.13-0.98 \mathrm{mg} / \mathrm{g}$ for AEB Formation, indicating a poor to fair quality source rock (Fig. 4).

Remaining hydrocarbon generative potential (S2) represents the amount of hydrocarbons generated through thermal cracking (at 300-550 C) of the contained kerogen (Waples, 1985). Khatatba Formation showed better capability of hydrocarbon generation (S2) compared to AEB Formation. S2 values indicate poor to very goodquality source rock potential for Khatatba Formation with an average of $14.72 \mathrm{mg} / \mathrm{g}$ and a range of $0.29-48.8 \mathrm{mg} / \mathrm{g}$. As for AEB Formation S2 yielded an average of 0.88 $\mathrm{mg} / \mathrm{g}$ and a range of $0.37-1.52 \mathrm{mg} / \mathrm{g}$ indicating poorquality source rock (Fig. 4).

Rock-Eval pyrolysis analysis, HI, provided an average of 100 and a range of $65-132 \mathrm{mg} / \mathrm{g}$ TOC for AEB Formation indicating kerogen type III (no liquid generation). It also gave an average of $161 \mathrm{mg} / \mathrm{g}$ TOC and a range of $20-264 \mathrm{mg} / \mathrm{g}$ TOC for the Khatatba Formation, reflecting kerogen type III to kerogen type III \& II (marginal potential for liquid generation) (Fig. 4).

Genetic Potential (GP) was used to determine the type and potentiality of a source rock. It averages 1.15 and ranges from 0.52 to $1.84 \mathrm{mg} / \mathrm{g}$ for AEB Formation, reflecting poor genetic potential while in Khatatba Formation it averages $15.5 \mathrm{mg} / \mathrm{g}$ and ranges from 0.45 to $50.34 \mathrm{mg} / \mathrm{g}$, indicating poor to very good genetic potential, with most samples plotting within the zone of very good genetic potential (Fig. 4).

Vitrinite reflectance (Ro \%) is a widely used indicator for reflecting the thermal maturity of kerogen, because it extends over a longer maturity range than any other indicator (Waples, 1985). Ro \% showed that AEB Formation and Khatatba Formation are thermally immature to very mature (Fig. 4). The thermal maturity increases with depth and reaches its maximum in Khatatba Formation. Ro $\%$ of AEB Formation averages $0.7 \%$ and ranges from 0.18 to $1.7 \%$, and for the Khatatba Formation it averages of $0.78 \%$ and ranges from 0.26 to $1.85 \%$ (Fig. 4).

The Tmax value is the temperature at the maximum point of "S2" peak released from Rock-Eval Pyrolysis and can be used to determine the degree of thermal maturity of the sedimentary organic matter. Tmax of AEB Formation averages $434 \mathrm{o} \mathrm{C}$ and ranges from 431 o $\mathrm{C}$ to $437 \mathrm{o} \mathrm{C}$ while it averages $450 \mathrm{o} \mathrm{C}$ and ranges from $434 \mathrm{o} \mathrm{C}$ to $459 \mathrm{o} \mathrm{C}$ for the Khatatba Formation (Fig. 4).

\section{Maturity and thermal burial history:}

One-dimensional modeling was applied on geochemical data from TUT-22X to clarify the influence of the tectonic evolution of the basin on the heat-flow distribution through time. The reconstruction of the thermal history of the basin is simplified and calibrated against profiles of maturity (e.g., vitrinite reflectance and temperature). The heat-flow values during the tectonic development were estimated and calibrated using measured temperature from sediments of both formations. Vitrinite reflectance of approximately $0.6 \%$ Ro indicates that the source rock reached the top of the oil window at depth $>8000 \mathrm{ft}$ and reached the early oil stage during the late Cretaceous at about 68 my for AEB Formation and at 92 my for the Khatatba Formation. Figure (5) displays the maturity levels and the thermal burial history model along with temperature fitting. It illustrates the relationship between depth (ft) and Age (my) where the total depth reached to more than $12500 \mathrm{ft}$. The temperature increases systematically with depth from surface temperature. The studied wells seem to have reached the maximum temperatures in the Neogene time.

\section{Petrophysical modeling:}

The 3D petrophysical models of the reservoir parameters varying with depths included the shale volume, total porosity, effective porosity, and hydrocarbon saturation (Fig. 6). Descriptive statistics of the studied parameters are shown in Table 2. Reservoirs and pay zones are then demarcated from the analyses of the saturation with either hydrocarbon, water, or both (Fig. 7 ). The effective porosity (Фeff) measures the void spaces that are filled with recoverable oil or gas sufficiently interconnected to yield economical oil/ gas flow (North, 1985). Water saturation (Sw) is the fraction of pore volume occupied by formation water (Schlumberger, 1972) while the hydrocarbon saturation measures the pore volume that contains hydrocarbons.

The shale volume 3D model shows an upwards and north-eastwards increase in the volume of shale. The volume of shale is larger in AEB Formation than in Khatatba Formation (Fig. 4A). The shale volume averaged $11.5 \%$ and $7.17 \%$ and shows a range of $0-25 \%$ and $5-11$ $\%$ for AEB and Khatatba formations, respectively. The shale volume isosurfaces at values of $5 \%, 10 \%, 15 \%$ and $20 \%$ display the spatial 3D distribution of the shale volume (Fig. 6B).

Total porosity $(\Phi t)$ increases north-eastwards with higher values in AEB Formation than in Khatatba Formation (Fig. 6). $\Phi$ t averaged $15.4 \%$ and $11.82 \%$ and showed a range of $0-24 \%$ and $10-13 \%$ for AEB and Khatatba formations, respectively. Effective porosity (Фeff) averaged $12.29 \%$ and $9.63 \%$ and shows a range of $0-18 \%$ and $8-10 \%$ for AEB and Khatatba formations, respectively. Фeff increases north-eastwards with higher values in AEB Formation than in Khatatba Formation (Fig. 6).

The average hydrocarbon saturation (Sh) values are $52 \%$ and $80 \%$ with ranges of $0-90 \%$ and $68-85 \%$ for AEB and Khatatba formations, respectively (Fig. 6A). Figure (6B) displays the $\mathrm{Sh}$ isosurfaces of the hydrocarbon saturation at $30 \%, 50 \%, 70 \%$ and $80 \%$ where the surfaces of 30 and $50 \%$ are confined to AEB Formation and surfaces of 70 and $80 \%$ marked the Khatatba Formation. 
Modeled reservoirs and pay zones are of marked thicknesses and in AEB-1, AEB-2, AEB-3A, AEB-3D, AEB-3E and Khatatba units (Fig. 7).

\section{Conclusions:}

Evaluation of the hydrocarbon potential in the Shoushan Basin, Tut Oil Field, was significantly improved with an integrated $3 \mathrm{D}$ basin analysis that provided a useful means towards understanding the variation of various parameters with depth. Rock-Eval pyrolysis and petrophysical and 3D models enabled spatial tracing of organic carbon richness, types of organic matter, and thermal maturation level, along with the porosity, hydrocarbon saturation, reservoirs and pay zones for the
Middle Jurassic Khatatba and Lower Cretaceous AEB formations imaged in ten wells.

TOC (wt \%) indicates poor to very good and fair to good source rock quality for Khatatba Formation and AEB Formation, respectively. Volatile hydrocarbons (S1) clarify poor to very good source rock for Khatatba Formation and poor to fair source rock for AEB Formation. Khatatba Formation showed better capability of hydrocarbon generation (S2) compared to AEB Formation. S2 indicates poor to very good source potential of Khatatba Formation and poor source rock for AEB Formation. Khatatba Formation had mainly kerogen type 
Table 1: Rock-Eval pyrolysis and vitrinite reflectance analysis of TUT-22X well.

\begin{tabular}{||c|c|c|c|c|c|c|c|c||}
\hline Formation & & TOC wt $\%$ & S1 (mg/g) & S2 (mg/g) & HI (mg/g) & GP (mg/g) & Ro\% & Tmax ${ }^{\circ} \mathbf{C}$ \\
\hline \multirow{4}{*}{ AEB } & Min. & 0.53 & 0.13 & 0.37 & 65 & 0.52 & 0.18 & 431 \\
\cline { 2 - 10 } & Max. & 1.54 & 0.98 & 1.52 & 132 & 1.84 & 1.71 & 437 \\
\cline { 2 - 10 } & Mean & 0.88 & 0.26 & 0.88 & 100.2 & 1.14 & 0.70 & 434.2 \\
\hline \multirow{3}{*}{ KHATATBA } & Min. & 0.32 & 0.14 & 0.29 & 20 & 0.45 & 0.26 & 434 \\
\cline { 2 - 10 } & Max. & 33.5 & 2.21 & 48.8 & 264 & 50.3 & 1.85 & 459 \\
\cline { 2 - 10 } & Mean & 6.69 & 0.69 & 14.72 & 161.3 & 15.4 & 0.78 & 450.4 \\
\hline
\end{tabular}

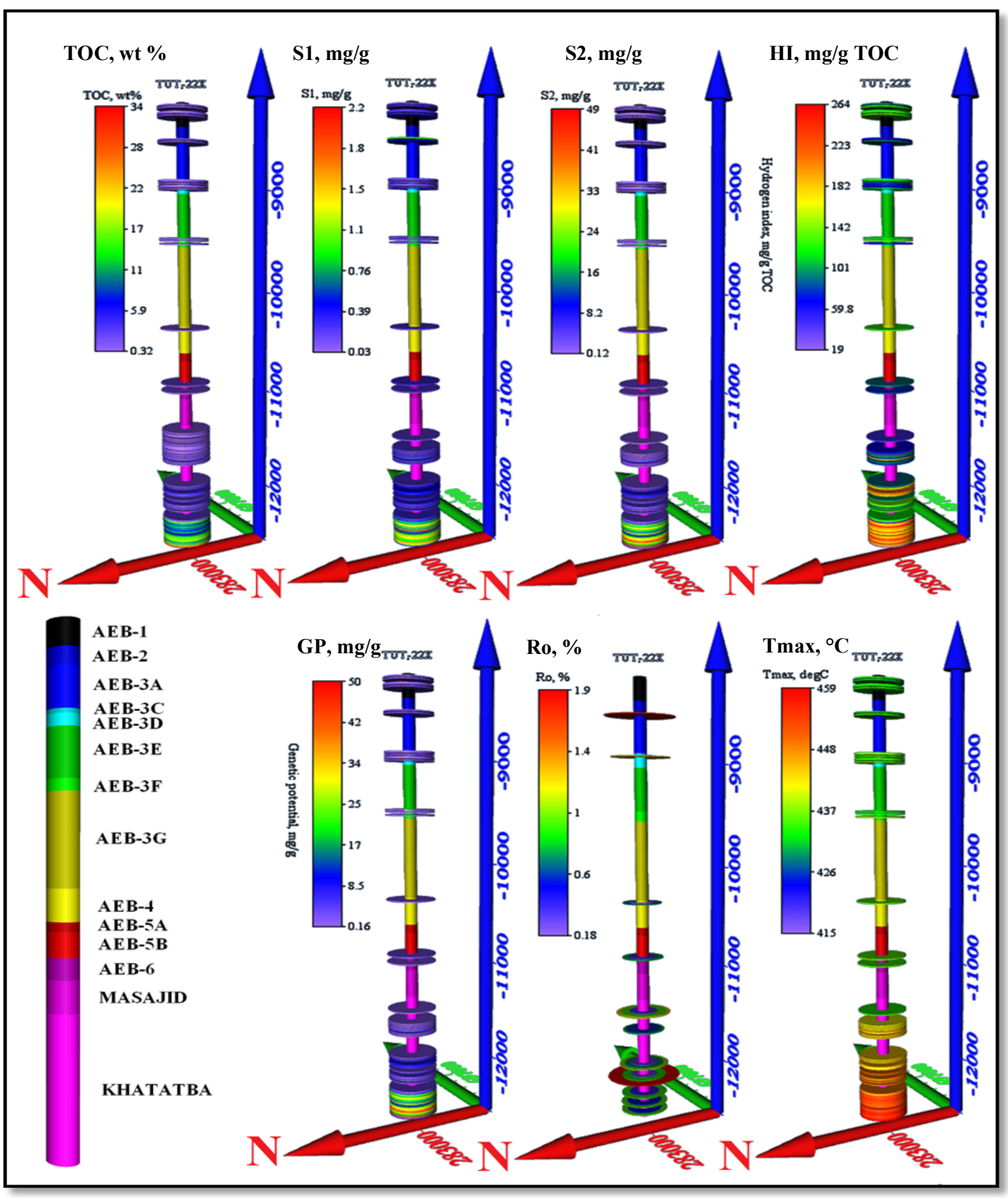

Fig. 4: 3D geochemical parameters for TUT-22X well. 

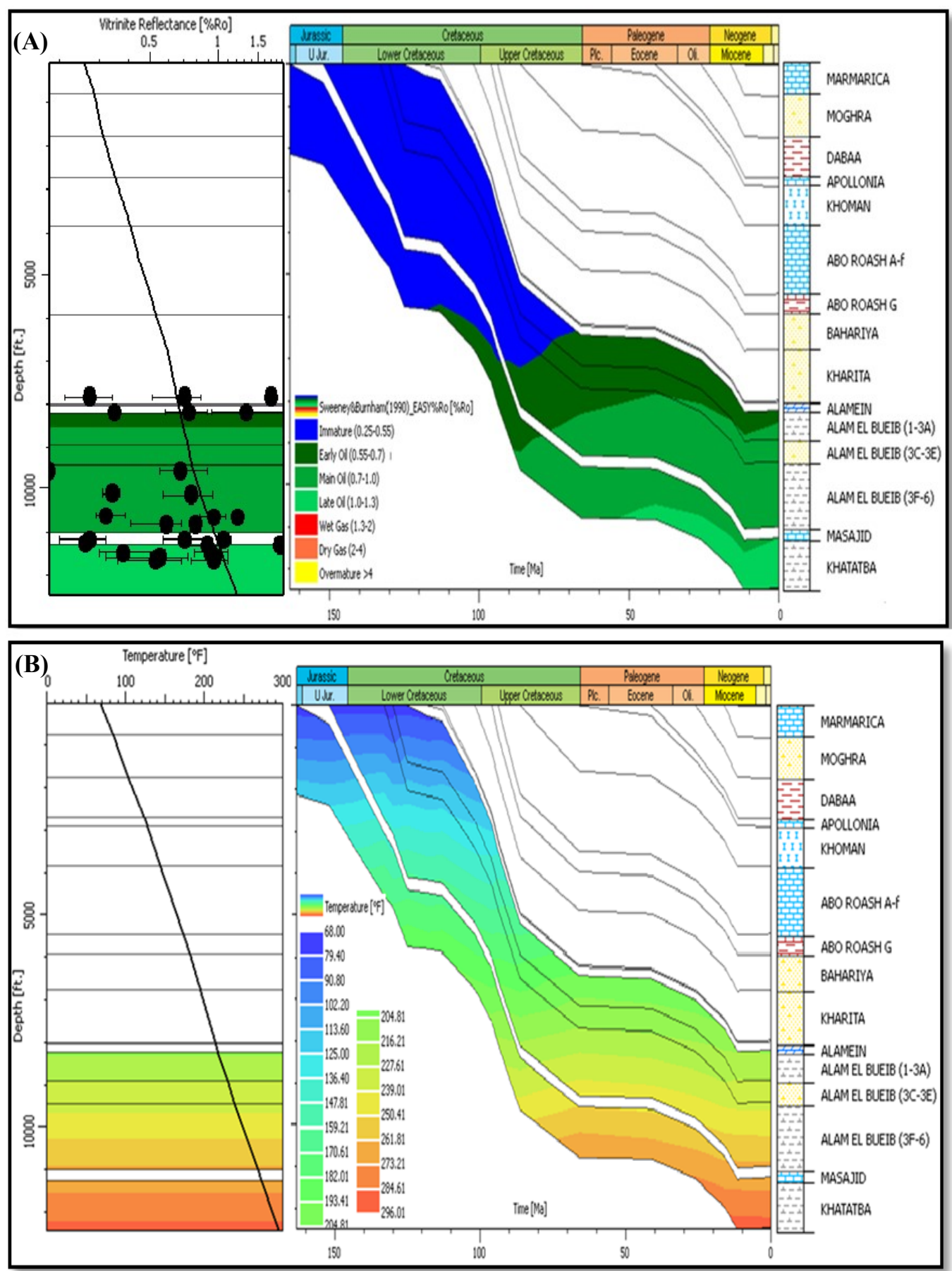

Fig. 5: Diagram discriminating maturity levels (A) and thermal burial history (B) in TUT-22X well. 
Table 2: Tut oil field Petrophysical parameters of the AEB and Khatatba formations.

\begin{tabular}{|c|c|c|c|c|c|}
\hline Formation & & $\Phi_{t}, \%$ & $\Phi_{\text {eff }}, \%$ & Vsh, \% & Sh, \% \\
\hline \multirow{3}{*}{ AEB-1 } & Min. & 14.8 & 10.7 & 9.9 & 20.2 \\
\hline & Max. & 24.3 & 16.4 & 24.9 & 73.3 \\
\hline & Mean & 18.51 & 13.79 & 17.43 & 59.6 \\
\hline \multirow{3}{*}{ AEB -2 } & Min. & 0 & 0 & 0 & 0 \\
\hline & Max. & 22.4 & 15.5 & 20.6 & 78.9 \\
\hline & Mean & 12.71 & 9.6 & 10.79 & 40.75 \\
\hline \multirow{3}{*}{ AEB -3A } & Min. & 12.4 & 9.5 & 7.4 & 1 \\
\hline & Max. & 19.8 & 18 & 22.3 & 75.3 \\
\hline & Mean & 16.74 & 13.28 & 13.01 & 47.09 \\
\hline \multirow{3}{*}{ AEB -3D } & Min. & 0 & 0 & 0 & 0 \\
\hline & Max. & 19 & 17.7 & 19.4 & 89.6 \\
\hline & Mean & 12.79 & 10.32 & 9.07 & 65.31 \\
\hline \multirow{3}{*}{ AEB -3E } & Min. & 10.9 & 9.2 & 4 & 1 \\
\hline & Max. & 21.7 & 18.3 & 13.8 & 86.7 \\
\hline & Mean & 16.25 & 14.46 & 7.57 & 46.26 \\
\hline \multirow{3}{*}{$\begin{array}{c}\text { AEB } \\
\text { TOTAL }\end{array}$} & Min. & 0 & 0 & 0 & 0 \\
\hline & Max. & 24.3 & 18.3 & 24.9 & 89.6 \\
\hline & Mean & 15.4 & 12.29 & 11.57 & 51.8 \\
\hline \multirow{3}{*}{ КНАТАТВА } & Min. & 10 & 8 & 4.9 & 68.3 \\
\hline & Max. & 13.3 & 10.6 & 11.3 & 85.7 \\
\hline & Mean & 11.82 & 9.63 & 7.17 & 80.15 \\
\hline
\end{tabular}



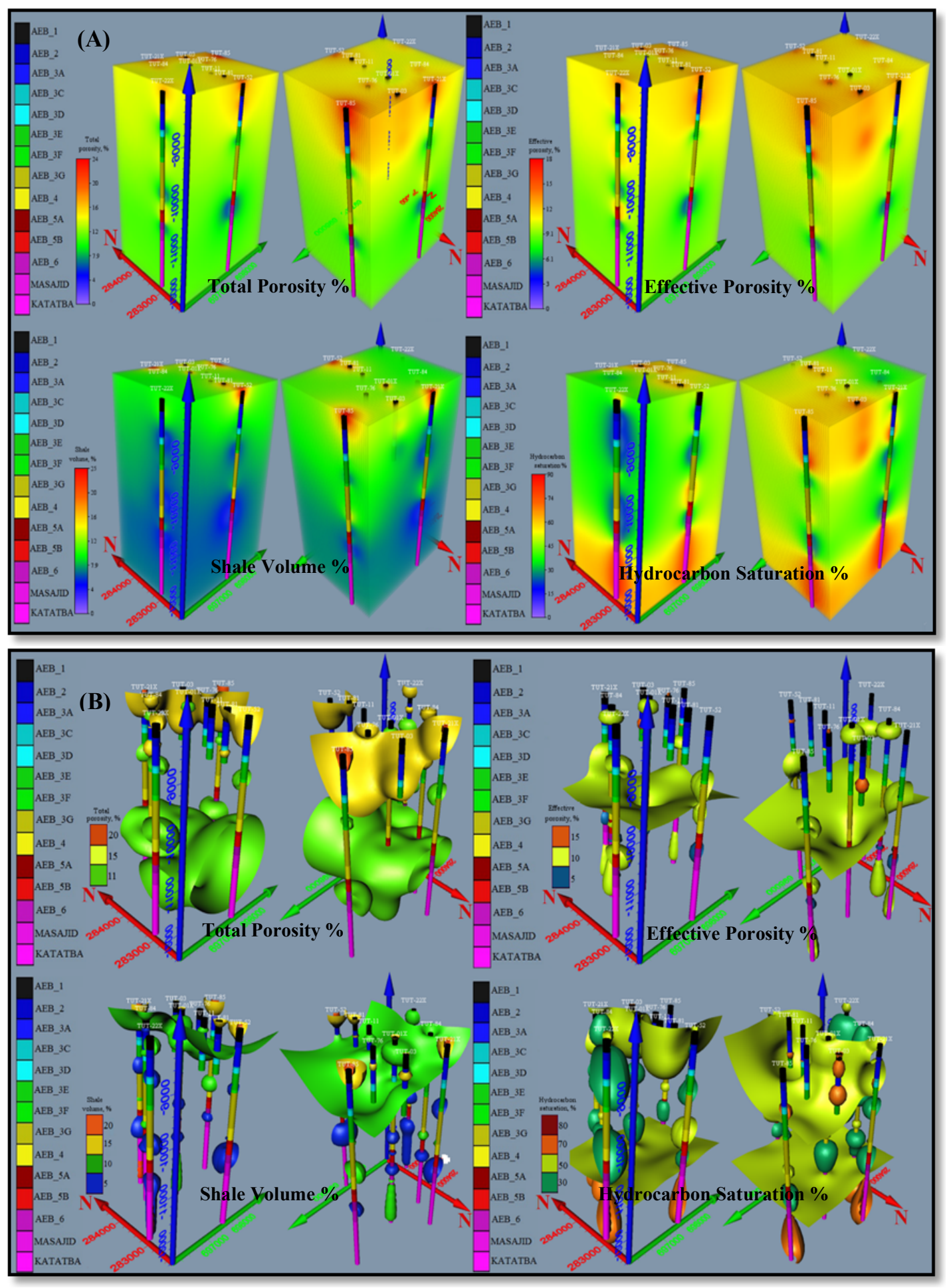

Fig. 6: Petrophysical parameters in 3D volume render (A) and isosurface (B) of TUT wells. 


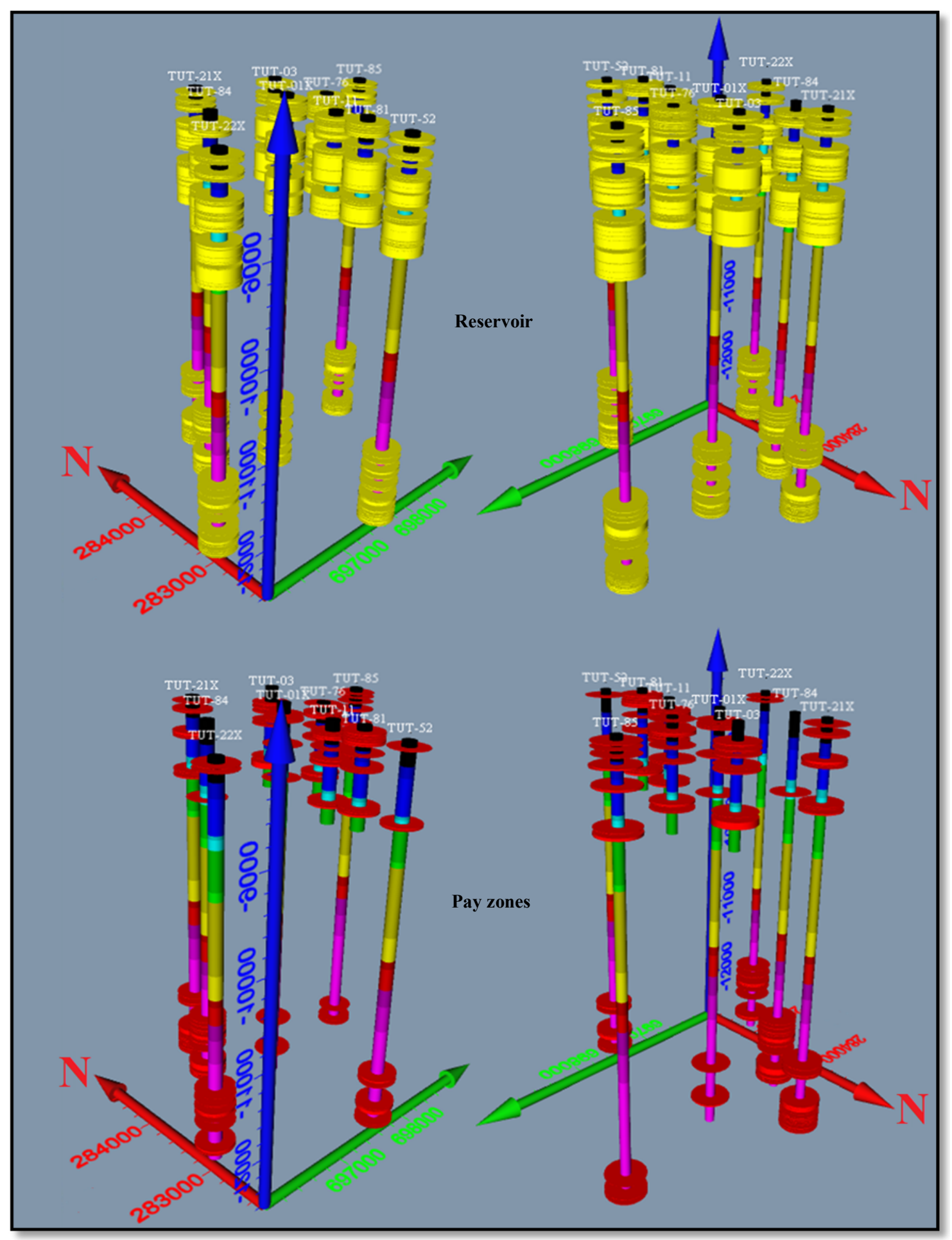

Fig. 7: 3D models of the reservoirs (up) and pay zones (down) of TUT wells. 
III to kerogen type III \& II (marginal potential for liquid generation) while kerogen type III marked AEB Formation. Source rock generation potential (GP) is poor in AEB Formation and very good in Khatatba Formation. Thermal maturation from the measured \%Ro reflects that AEB Formation and Khatatba Formation are thermally immature to very mature source rocks. The thermal maturity increases with depth and reaches its maximum in Khatatba Formation. Neogene time recorded the maximum temperatures in the studied wells. Tmax values are much higher in Khatatba Formation compared to AEB Formation. The source rock reached the early oil stage during the late Cretaceous at about 68 my for AEB Formation and at 92 my for the Khataba Formation. From these geochemical results, Khatatba Formation is much more effective as source rock for hydrocarbon accumulation compared to AEB Fm.

The 3D petrophysical models show the spatial distribution of the studied reservoir log-derived parameters with varying depths. The models show northeastward gradual increase in porosity, hydrocarbon saturation, thicknesses of pay zones, and decrease of water saturation. It is, therefore, recommended that future exploration practices should be favourably directed northeastward. Models also confirm that the northwestern and southwestern parts with larger depths encountered commonly in Khatatba Formation are very good for hydrocarbon accumulation and production.

The shale volume 3D model shows an upwards and north-eastwards increase in the volume of shale. The mean volume of shale is larger in AEB Formation. (11.5\%) than in Khatatba Formation $(7.17 \%)$. The porosity (total, and effective) increase north-eastwards with higher mean values in AEB Formation $(15.4 \%, 12.29 \%)$ than in Khatatba Formation $(11.82 \%, 9.63 \%)$.

The mean hydrocarbon saturation (Sh) is higher in Khatatba Formation $(80 \%)$ than in AEB Formation (52 $\%$ ). Thicknesses and frequencies of occurrences of the modeled reservoirs and pay zones marked higher in AEB1, AEB-2, AEB-3A, AEB-3D, AEB-3E and Khatatba formations.

\section{Acknowledgments:}

Thanks are due to authorities of the Egyptian General Petroleum Corporation (EGPC), Cairo, Egypt for their permission to carry out this study. Thanks also go to the authority of Khalda Petroleum Company, Cairo, Egypt, for providing the required geological, geophysical and geochemical data.

\section{References:}

Abdelkader, T.A.A., 2012: Sedimentological Studies and Oil Potentiality of the Subsurface Bahariya Formation in Khalda Field, Northern Western Desert, Egypt. Ph.D. Thesis. Tanta University, Egypt. 260 p.

Abdou A.A., Shehata M.G., and Kassab M.A.M., 2009: Petrography and probable reservoir potentiality of subsurface Jurassic rocks at Abu Gharadiq Basin and Shoushan Subbasin, north Western Desert, Egypt. Aust J Basic Appl Sci 3:1206-1222.

Carlos R., Rafaela M., Karl R., and Albert P., 2001: Facies-related diagenesis and multiphase siderite cementation and dissolution in the reservoir sandstones of the Khatatba Formation, Egypt's Western Desert. J Sediment Res 71. 459-472.

El-Bastawesy, M., 2013. Sedimentological Studies and Hydrocarbon Potentialities of the Jurassic Safa Formation, North Western Desert, Egypt. M.Sc. Thesis. Tanta University, Egypt, 184 p.

El Nady, M. M. 1999. Contribution to petroleum source rocks and thermal maturation of Cretaceous sequence in the West Razzak-Alamein area, North Western Desert, Egypt. Egyptian Journal of Petroleum, 8, 8799.

E1 Nady, M.M., 2015. Evaluation of the nature, origin and potentiality of the subsurface Middle Jurassic and Lower Cretaceous source rocks in Melleiha G-1x well, North Western Desert, Egypt. Egyptian Journal of Petroleum, doi:10.1016/j.ejpe.2015.07.012.

El Nady, M.M., and Ghanem, F.M. 2011. Thickness Variations, Lithofacies Changes, and Time of Hydrocarbons Generation in the Khalda West Area, North Western Desert, Egypt. J. Energy Source 33 (23), 2218-2229.

Espitalie, J., Deroo, G., and Marquis, F., 1985. Rock Eval pyrolysis and its applications. Revue de l'Institut Francais du Pe'trole Part I 40, 653-578, Part II 40, 755- 784, Part III 41, 73- 89.

Espitalie, J., Laporte, J.L., Madec, M., Marquis, F., Leplat, P., Paulet, J., and Boutefeu, A., 1977. Me'thode rapide de caracte'risation des roches me'res de leur potentiel pe'trolier et de leer degre' d'e'volution. Revue de l'Institut Francais du Pe'trole $32,23-42$.

Google Earth 7.1. 2015: Hylands House and estates $51^{\circ} 42^{\prime} 39.17^{\prime \prime} \mathrm{N}, \quad 0^{\circ} 26^{\prime} 11.30^{\prime \prime} \mathrm{W}$, elevation $60 \mathrm{M}$. 3D Buildings data layer.

Hanter, G., 1990: North Western Desert. In: Said, R. (eds.). The geology of Egypt. A. A. Balkema, Rotterdam, Netherlands. pp. $293-319$.

Issawi, B., El Hinnawi, M., Francis, M., and Mazhar, A., 1999. The Phanerozoic geology of Egypt: A geodynamic approach. Egyptian Geological Survey Special Publications, v. 76, 462 p.

Khalda Petroleum Company Geochemical Internal Report, Well TUT-22X, TUT Oil Field, 1996.

Metwalli, F.I., and Pigott, J.D., 2005. Analysis of petroleum system criticals of the Matruh-Shushan Basin, Western Desert, Egypt. Petroleum Geoscience 11(2), 157-178.

Nassar, H., 2013. Sedimentological Studies and Hydrocarbon Potentiality of the Lower Cretaceous Alam El-Bueib Formation, North Western Desert, Egypt. M.Sc. Thesis. Tanta University, Egypt, 236 p.

North, F. K., 1985. Petroleum geology. Allen and Unwin Inc., $581 \mathrm{p}$.

Peters, K.E., 1986: Guidelines for evaluating petroleum source rock using programmed pyrolysis. AAPG Bull., 70: 318-329.

Ramadan, F.S., Metwalli, F.I., El-Khadragy, A.A., and Afify, W., 2012. The Subsurface Geology And Source Rocks Characteristics Of Some Alam El Bueib Reservoirs In Tut Oil Field, North Western Desert, Egypt. J. Appl. Sci. Res. 8 (11), 5388-5409. 
Schlumberger, 1972: The essential of log interpretation practice. Schlumberger Ltd., France, pp 45-67.

Schlumberger, 1984: Well evaluation conference, Egypt. Geology of Egypt, pp. 1-64.

Schlumberger, 1995: Well Evaluation Conference, Egypt. Schlumberger Technical Editing Services, Chester. pp. 58-66.

Shalaby, M.R., Hakimi, M.H., and Abdullah, W.H., 2011. Geochemical characteristics and hydrocarbon generation modeling of the Jurassic source rocks in the Shoushan Basin, north Western Desert, Egypt. Marine and Petroleuom Geology 28(9), 1611-1624.

Shalaby, M. R., Hakimi, M. H., and Abdullah, W.H., 2012. Organic geochemical characteristics and interpreted depositional environment of the Khatatba Formation, northern Western Desert, Egypt. AAPG Bulletin 96(11), 2019-2036.

Shalaby M.R., Hakimi M.H., and Abdullah W.H., 2013: Modeling of gas generation from the Alam El-Bueib formation in the Shoushan Basin, northern Western Desert of Egypt. Int J Earth Sci 102: 319-332.

Sharaf, L. M., and El Nady, M. M. 2003.Geochemical characterization of source rocks and oil-source rocks correlation in some Wells within South Umbarka Area, North Western Desert, Egypt. J. Egyptian Sedimentology 11, 61-76.

Sharaf, L. M., Ghanem, M. F., Hussein, S.A., and El Nady, M.M., 1999. Contribution to petroleum source rocks and thermal maturation of Jurassic-Cretaceous sequence, South Matruh, Northern Western Desert, Egypt: J. Sedimentology of Egypt. 7, 71-83.

Sweeney, J.J., and Burnham, A.K., 1990. Evaluation of a simple model of vitrinite reflectance based on chemical kinetics. American Association of Petroleum Geologists Bulletin 74 (10), 1559-1570.

Waples, D.W., 1985. Geochemistry in petroleum exploration. International Human Resources Development Corporation, Boston, 232 p.

Zein El-Din, M.Y., Abd El-Gawad, E.A., El-Shayb, H.M., and Haddad, I.A., 2001: Geological studies and hydrocarbon potentialities of the Mesozoic rocks in Ras Kanayis onshore area, North Western Desert, Egypt. Annals of the Geological Survey of Egypt, XXIV, 115-134.

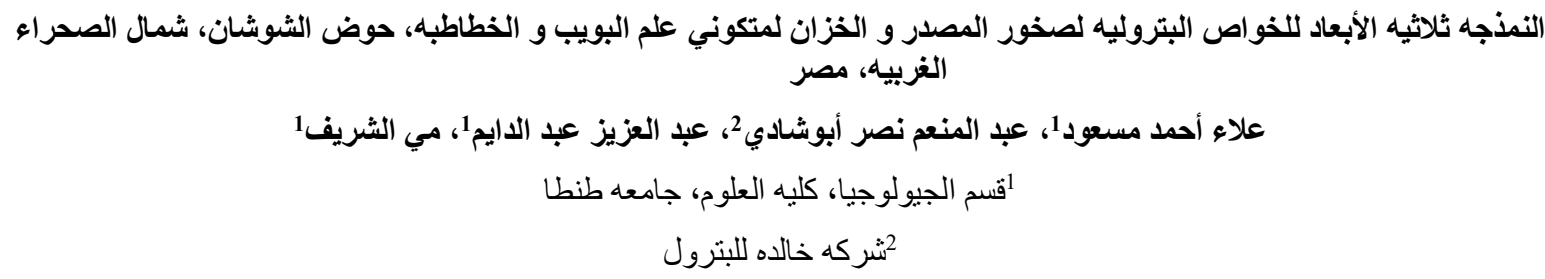

يهدف البحث إلى عمل نموذج ثلاثي الأبعاد للنطاقات ذات الإنتاجيه العاليه للبترول في مكون علم البويب في العصر الطاثيري و مكون

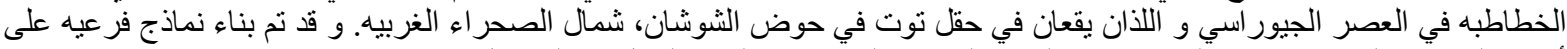

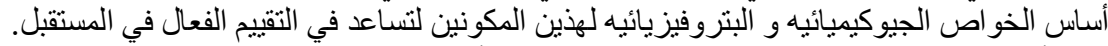

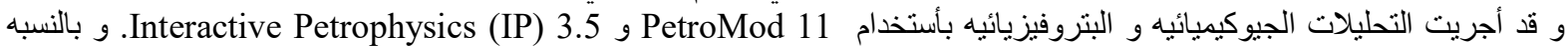

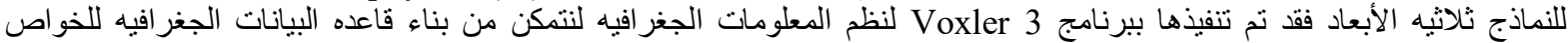

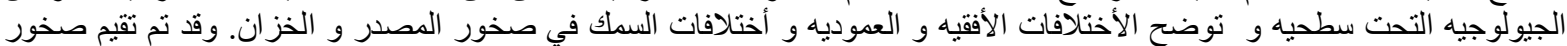

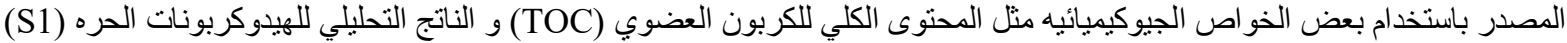

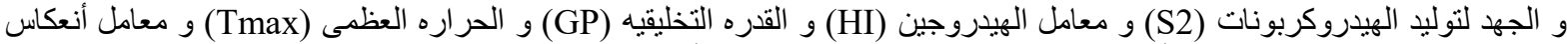

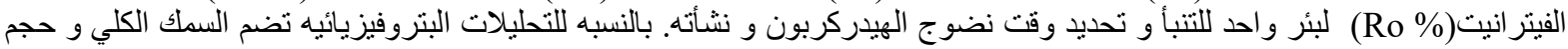

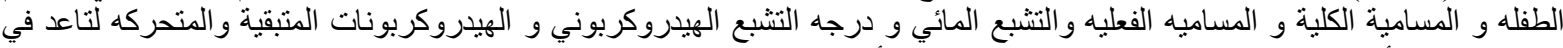

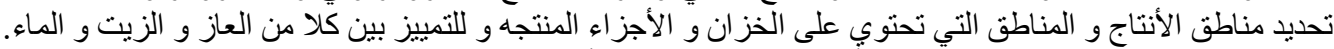

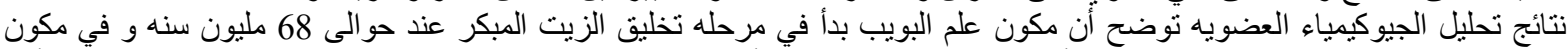

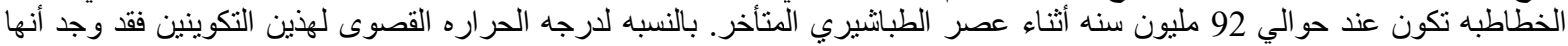

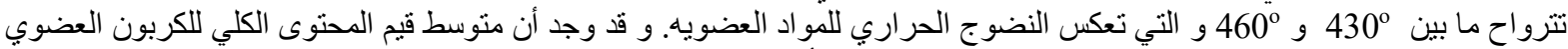

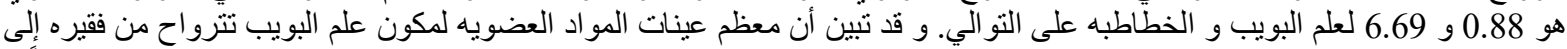

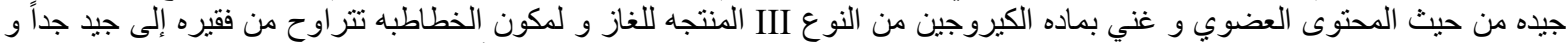

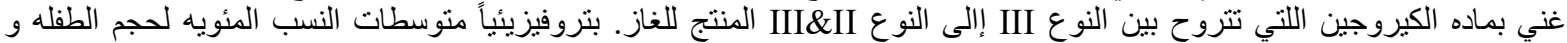

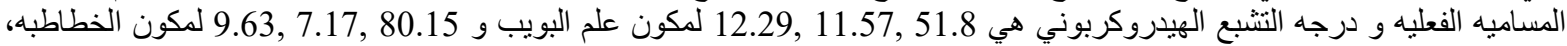
على التو الي. و قد تم نماذج ثلاثيه الأبعاد للخو اصل السحنيه و الجيوكيميائيه و البتروفيزيائيه للتمكين من تقييم النظام البترولي و أماكن أحتمال تواجد

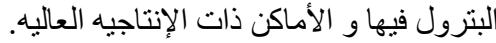

